\title{
Energy Production from Thermal Gasification of Selected Solid Wastes from Kiambu County,Kenya
}

\author{
Mugo Ephantus ${ }^{1}$, Kinyua Robert ${ }^{2}$, Yasuyuki Nemoto ${ }^{3}$, Njogu Paul ${ }^{4}$ \\ 1, 2, 4 Institute of Energy and Environmental Technology, Jomo Kenyatta University of Agriculture and Technology, P. O. Box 62000-00200, \\ NAIROBI, KENYA.
}

${ }^{3}$ Division of Renewable Energy and Environment, Ashikaga Institute of Technology, Japan

\begin{abstract}
Increased population growth resources competition and the diminishing of conventional energy sources calls for development of innovative technologies for power generation Thermal gasification is a promising technology for conversion of carbonaceous waste into energy resources such as synthesis/producer gas-(methane, carbon monoxide (CO), hydrogen (H) and carbon dioxide $\left(\mathrm{CO}_{2}\right)$ and other gases).The study assessed the potential for conversion of rice husks, maize cobs and sawdust to energy resources by thermal gasification using a locally assembled gasifier. Rice husks, maize cobs and sawdust samples were collected and dried to a moisture content of $<8 \%$. The process parameters that were controlled included temperature, pressure, process time and air injection. The resultant gas was upgraded by passing it through a series of wood shavings filters before collecting it for analysis. Portions of $1 \mathrm{~cm}^{3}$ syngas samples were sampled and injected into a gas chromatograph with thermal conductivity detector (GC-TCD) to determine the concentration of $\mathrm{CO}_{2}, \mathrm{CO}, \mathrm{CH}_{4}, \mathrm{H}_{2}, \mathrm{~N}_{2}$, and $\mathrm{O}_{2}$. Results show that $25 \mathrm{Kg}$ of rice husks, produced $580 \pm 4.2 \mathrm{~m}^{3}$ of syngas, while sawdust and maize cobs produced $480 \pm 2.8 \mathrm{~m}^{3}$ and $420 \pm 3.1 \mathrm{~m}^{3}$ respectively.Syngas derived from rice husk contained $9.81 \pm 0.99 \%$ $\mathrm{CH}_{4}, 28.55 \pm 0.99 \% \mathrm{CO}, 12.59 \pm 0.99 \% \mathrm{CO}_{2} 7.44 \pm 0.99 \% \mathrm{~N}_{2}, 8.34 \pm 0.99 \% \mathrm{O}_{2}$ and $34.06 \pm 1 \% \mathrm{H}_{2}$ while that from sawdust contained $12.06 \pm 1.13 \% \mathrm{CH}_{4}, 34.34 \pm 1.13 \% \mathrm{CO}, 8.24 \pm 1.1 \% \mathrm{CO}_{2} 5.11 \pm 1.1 \% \mathrm{~N}_{2}, 5.96 \pm 1.13 \% \mathrm{O}_{2}$ and $34.4 \pm 1.1 \% \mathrm{H}_{2}$ respectively. The calorific value of syngas derived from sawdust was approximately $16 \mathrm{MJ} / \mathrm{m}^{3}$. Rice husks and maize cobs produced $13 \mathrm{MJ} / \mathrm{m}^{3}$ and $12 \mathrm{MJ} / \mathrm{m}^{3} \mathrm{respectively}$. The high content of $\mathrm{CH}_{4}$ and $\mathrm{CO}$ in sawdust contributes to its higher calorific value than rice husk. This gas is therefore sufficient to directly drive a 10-kWe AC synchronous generator at a speed of 1,800 rpm producing 220 volt current, which can supply a total of 16 pieces of 50-watt bulbs, can be energized by the plant for 8 to 10 hours continuous operation. The results indicate that there is potential of energy production from carbonaceous wastes. Independent power producers can adopt this waste to energy (WtE) conversion technology.
\end{abstract}

Keywords: Solid wastes, gasification, WtE, rice husks, saw dust, maize cobs, syngas

\section{Introduction}

Gasification or controlled partial oxidation of a carbonaceous material, and it is achieved by supplying less oxygen than the stoichiometric requirement for complete combustion. Air (or oxygen in some applications) is used as a gasification agent, and the air factor is generally $20 \%$ $40 \%$ of the amount of air needed for the combustion (Daniela et al.,2002). A central process between combustion (thermal decomposition with excess oxygen) and pyrolysis (thermal decomposition in the absence of oxygen), it proceeds at temperatures ranging between $600^{\circ} \mathrm{C}$ and $800^{\circ} \mathrm{C}$. Depending upon the process type and operating conditions, low- or medium-value producer gas (which is a combination of combustible and non-combustible gases) is created (Doherty et al.,2009; Jaojaruek et al.,2011). The main feature of this technology is its ability to produce a reliable, high-quality synthesis gas (syngas) product that can be used for energy production. The primary product of this gaseous mixture is carbon monoxide and hydrogen, with minor percentages of gaseous hydrocarbons also formed. The thermo chemical conversion changes the chemical structure of the biomass by means of high temperature. The gasification agent allows the feedstock to be quickly converted into gas by means of different heterogeneous reactions (Kathirvale et al., 2004; Narvaez et al., 2004; Singh et al.,2011).The combustible gas contains $\mathrm{CO}_{2}, \mathrm{CO}$, $\mathrm{H}_{2}, \mathrm{CH}_{4}, \mathrm{H}_{2} \mathrm{O}$, trace amounts of higher hydrocarbons, inert gases present in the gasification agent, various contaminants such as small char particles, ash and tars(Themelis et al., 2003).

\section{Materials and Methods}

\subsection{Area of Study}

This study was carried out in Thika Municipality of Kiambu County. The study area lies between latitudes $3^{\circ} 53^{\prime}$ and $1^{\circ} 45^{\prime}$ south of Equator and longitudes $36^{\circ} 35^{\prime}$ and $37^{\circ} 25^{\prime}$ east (Robinson et al., 2005).

\subsection{Sample Collection}

Rice husks, maize cobs and saw dust samples were collected in pre cleaned polyethene bags, screened to remove large particles and sun dried to a constant weight before storage.

\subsection{Sample Treatment}

Rice husks, maize cobs and saw dust samples were dried by spreading them outside sunlight to reduce the moisture content. Samples of this waste were taken and tested to monitor the moisture levels before gasification.

\subsection{Data Collection}

Portions of 25 Kgs were fed into the gasifier and process parameters set. 


\section{International Journal of Science and Research (IJSR) \\ ISSN (Online): 2319-7064 \\ Index Copernicus Value (2013): 6.14 | Impact Factor (2015): 6.391}

\subsubsection{Thermal gasification of selected waste}

A gasifier with $40 \mathrm{~cm}$ internal diameter and a height of $200 \mathrm{~cm}$ reactor equipped with an electric air blower to provide the air needed in gasifying the feedstock was used. These samples were manually fed to the reactor from the top. On the other hand, char is removed from beneath the gasifier at the char box. The gas coming out of the reactor is conditioned by allowing it to pass through the gas-cleaning devices which consisted of wet scrubbers, tar condenser cyclone, and a series of two wood shavings packed filters. Fig. 1 shows the engineering drawing of an updraft gasifier used to undertake this experiment.

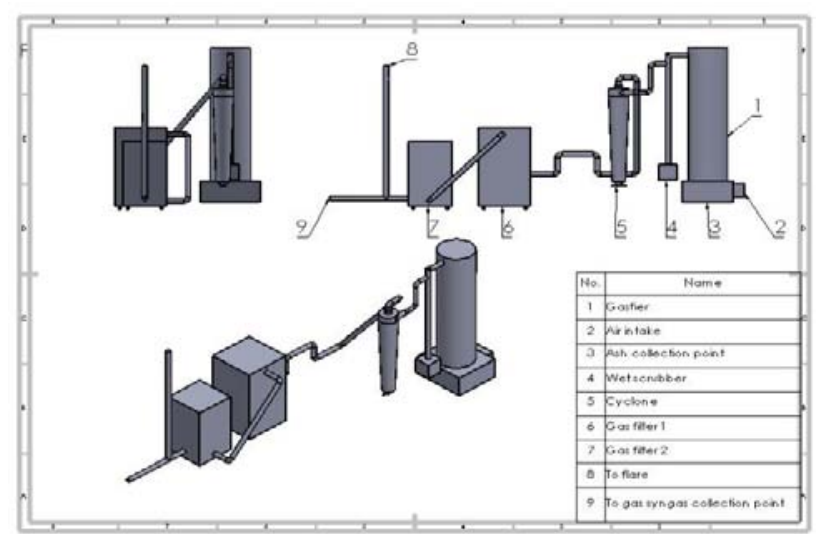

Figure 1: Engineering drawing of an updraft gasifier used to undertake this experiment

\subsubsection{Compositional analysis of syngas}

Syngas was analyzed as described by the American Standard Test method ASTM D2504-88(1998). Gas chromatograph with thermal conductivity detector (GC-TDC) model Shimadzu GC-8A and gas chromatography flame ionization detector (GC-FID)model Shimadzu GC-9A were used for the analysis. An isocratic mode was used since a constant temperature was maintained throughout the operation.

Portions of $1 \mathrm{ml}$ samples were injected into a gas chromatograph (GC-TCD) and the $\mathrm{CO}_{2}, \mathrm{CO}, \mathrm{CH}_{4}, \mathrm{H}_{2}, \mathrm{~N}_{2}$, and $\mathrm{O}_{2}$ concentrations were determined using a (TCD). The equipment were calibrated using gas standards and the gases indentified based on the retention time and the concentrations calculated from the peak areas. Analysis parameters used are as shown in the table 2.1.

Table 2.1: Operational conditions and analysis parameters

\begin{tabular}{|c|c|}
\hline Column Width 6 & Slope 50 \\
\hline Drift 0 & MIN. AREA 100 \\
\hline T.DBL 0 & STOP. Time 6 \\
\hline Attenuation factor 4 & Speed 10 \\
\hline Method 41 & Format 0 \\
\hline
\end{tabular}

Test was carried out in JKUAT food science laboratories.

\section{Results and Discussion}

\subsection{Gasification of Rice husks, maize cobs and saw dust}

The gasification experiment was operated at specified parameters and it yielded the results shown in Table 3.1.
Table 3.1: Operation process parameters for gasification

\begin{tabular}{|c|c|c|c|}
\hline Type of feedstock - Rice & \multicolumn{3}{|c|}{ Measured value } \\
\cline { 2 - 4 } husks & Rice husks & Sawdust & Maize cobs \\
\hline Total operation time (min) & 150 & 180 & 120 \\
\hline $\begin{array}{c}\text { Moisture content(\% wet } \\
\text { basis) }\end{array}$ & 7 & 7.8 & 7.5 \\
\hline Initial weight of feed (kg) & 25 & 25 & 25 \\
\hline Feed in air $\left(\mathrm{m}^{3} / \mathrm{min}\right)$ & 8.2 & 8.2 & 8.2 \\
\hline $\begin{array}{c}\text { Average reduction zone } \\
\text { temperature (at the } \\
\text { bottom) }\left({ }^{\circ} \mathrm{C}\right)\end{array}$ & $510 \pm 2.3$ & $410 \pm 2.1$ & $420 \pm 3.1$ \\
\hline $\begin{array}{c}\text { Average drying zone } \\
\text { temperature } \\
\text { (at the top) }\left({ }^{\circ} \mathrm{C}\right)\end{array}$ & $222 \pm 1.9$ & $222 \pm 1.7$ & $220 \pm 2.1$ \\
\hline Estimated gas yield $\left(\mathrm{m}^{3}\right)$ & $580 \pm 4.2$ & $480 \pm 2.8$ & $420 \pm 3.1$ \\
\hline $\begin{array}{c}\text { Average calorific value of } \\
\left.\text { syngas (MJ/Nm }{ }^{3}\right)\end{array}$ & $13.18 \pm 0.12$ & $16.17 \pm 0.23$ & $12.1 \pm 0.18$ \\
\hline
\end{tabular}

It took the gasifier between two and three hours to decompose the same amount of various feedstock used, with an average of $8.2 \mathrm{~m}^{3} / \mathrm{min}$ of feed in air.

\subsection{Syngas composition data}

The syngas generated was analyzed to establish its composition. Concentration versus peak area values was obtained for each standard gas and the sample concentrations were obtained from the appropriate calibration curves. For compound identification, standard gases were used. Fig.2.Chromatograms of the gas analysis, using Gas chromatograph thermal conductivity detector (GC-TDC) for each gas sample were used

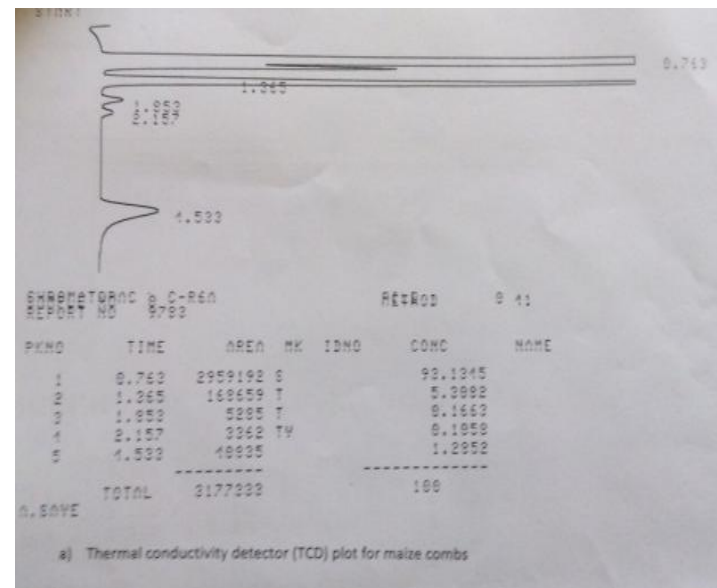

Figure 2: Shows some of the Chromatograms for this analysis

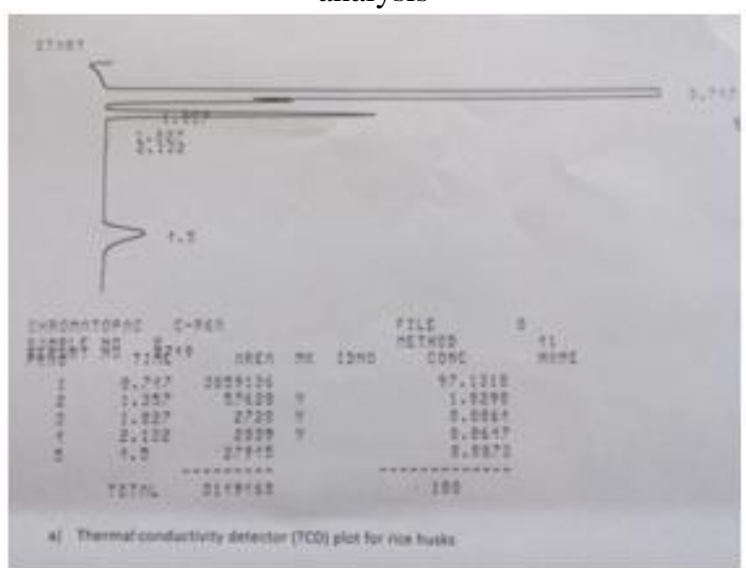




\section{International Journal of Science and Research (IJSR) \\ ISSN (Online): 2319-7064 \\ Index Copernicus Value (2013): 6.14 | Impact Factor (2015): 6.391}

The composition of syngas is presented in Table 2.

Table 2: Syngas composition data of selected waste

\begin{tabular}{|l|l|l|l|l|l|l|}
\hline $\begin{array}{l}\text { Parameters } \\
\text { measured }\end{array}$ & $\begin{array}{l}\text { Syngas from } \\
\text { rice husk } \\
\text { Average conc } \\
(\mathrm{ppb})\end{array}$ & Abundance \% & $\begin{array}{l}\text { Syngas from } \\
\text { sawdust } \\
\text { Average conc } \\
(p b)\end{array}$ & Abundance \% & $\begin{array}{l}\text { Syngas from } \\
\text { maize } \\
\text { Average } \\
\text { comb } \\
\text { conc }\end{array}$ & Abundance \% \\
\hline $\mathrm{CH}_{4}$ & $9.18 \pm 0.31$ & $9.81 \pm 0.99$ & $13.60 \pm 1.76$ & $12.06 \pm 1.13$ & $24.74 \pm 2.70$ & $22.02 \pm 1.10$ \\
\hline $\mathrm{CO}$ & $28.84 \pm 0.25$ & $28.55 \pm 0.99$ & $38.72 \pm 3.06$ & $34.34 \pm 1.13$ & $27.90 \pm 1.64$ & $24.83 \pm 1.12$ \\
\hline $\mathrm{CO}_{2}$ & $12.61 \pm 3.55$ & $12.59 \pm 0.99$ & $9.29 \pm 4.53$ & $8.24 \pm 1.10$ & $9.99 \pm 1.52$ & $8.89 \pm 1.12$ \\
\hline $\mathrm{N}_{2}$ & $7.51 \pm 0.15$ & $7.44 \pm 0.99$ & $5.76 \pm 0.76$ & $5.11 \pm 1.10$ & $7.44 \pm 0.11$ & $6.62 \pm 1.10$ \\
\hline $\mathrm{O}_{2}$ & $8.22 \pm 0.25$ & $8.34 \pm 0.99$ & $6.72 \pm 0.74$ & $5.96 \pm 1.13$ & $11.97 \pm 0.58$ & $10.65 \pm 1.12$ \\
\hline $\mathrm{H} 2$ & $34.4 \pm 0.12$ & $34.06 \pm 0.99$ & 38.79 & $34.40 \pm 1.10$ & $30.32 \pm 0.74$ & $30.32 \pm 1.12$ \\
\hline
\end{tabular}

\subsection{Estimation of energy derived from gasification of MSW}

While using saw dust the average volume of gas generated was $480 \mathrm{~m}^{3}$. The calorific value of this of the syngas is 16.17 $\mathrm{MJ} / \mathrm{m}^{3}$. This is equivalent to 4527.6 MJ. While using rice husks the average volume of gas generated was $580 \mathrm{~m}^{3}$. The calorific value of this of the syngas is $13.18 \mathrm{MJ} / \mathrm{m}^{3}$. This is equivalent to $7644.4 \mathrm{MJ}$. While using maize cobs the average volume of gas generated was $420 \mathrm{~m}^{3}$. The calorific value of this of the syngas is $12.1 \mathrm{MJ} / \mathrm{m}^{3}$. This is equivalent to $5082.0 \mathrm{MJ}$

Assuming 50\% thermal efficiency of the gas driven engine, then output energy of the engine is:

$$
\begin{gathered}
4527.6 \mathrm{MJ} \times 50 \%=2263.8 \mathrm{MJ} \\
7644.4 \mathrm{MJ} \times 50 \%=3822.2 \mathrm{MJ} \\
5082.0 \mathrm{MJ} \times 50 \% 2541.0 \mathrm{MJ}
\end{gathered}
$$

This is the mechanical input fed to a generator. Assuming the generator and the speed governor operate at 35\% efficiency and using the relationship of $1 \mathrm{kWh}$ of electricity output $=3.6 \mathrm{MJ}$ then,

$$
\begin{gathered}
\frac{2263 \times 35 \%}{3.6}=220.1 \mathrm{Kwh}-\text { for saw dust } \\
\frac{3822.2 \times 3}{3.6}=371.6 \mathrm{kwh}-\text { from rice husk } \\
\frac{2541.0 \times 35 \%}{3.6}=247.04 \mathrm{Kwh}-\text { from maize cob }
\end{gathered}
$$

This gas is therefore sufficient to directly drive a 10 -kWe AC synchronous generator at a speed of 1,800 rpm producing 220 volt current, which can supply a total of 16 pieces of 50-watt bulbs, can be energized by the plant for 8 to 10 hours continuous operation. Therefore the result shows that if this waste at the dumpsite was gasified it contains a lot of energy potential, whereby if a gasifier of higher efficiency is used there exists potential of converting this waste to useful energy resource.

\subsection{Syngas as a fuel for modified diesel engine.}

The gas was fueled to drive an engine. The engine ran at variable speed of between a minimum of 1852 to maximum of $3856 \mathrm{rpm}$. Shaft speed of the engine was measured using a digital tachometer as shown in figure 3 . The engine is entirely fueled by the gas generated, except at the start-up and at the end of the operation. The output of this engine shaft is coupled to generator to produce output electrical power.

\section{Volume 5 Issue 4, April 2016}

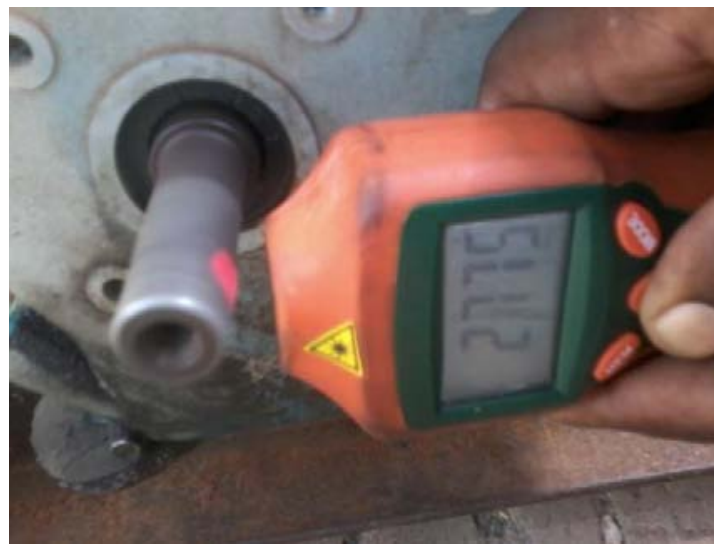

Figure 3: measuring the shaft speed of a gas driven engine using a digital tachometer

\section{Conclusion}

With the increasing industrialization and rapid population growth non renewable fuels are rapidly getting consumed, which may lead to risk of energy shortage in the future, but a definite solution to it is the use of renewable source. Conversion of waste to energy through gasification can be a good solution. Kenya being an agricultural country, there is ready availability of agricultural residues such as rice husk and maize cobs whereby adopting these gasifiers who produce a change in the energy scenario of the country.

\section{Acknowledgement}

Authors wish to acknowledge the Thika sub County Environment department officers, Jomo Kenyatta university of Agriculture and Technology food science Technology laboratory staff and JICA for providing funds and equipment.

\section{References}

[1] Daniela.T., Krisztina.U., Tanase.P., (2002).The effect of excess air ratio on syngas produced by gasification of agricultural residues briquettes. ISBN: 978-1-61804114-2.

[2] Doherty, W., Reynolds, A., Kennedy, D.,(2009). The effect of air preheating in a biomass CFB gasifier using ASPEN Plus simulation. Biomass and Bioenergy.Vol. 33, pp. 1158-1167

[3] Jaojaruek, K., Jarungthammachote, S., Gratuito, M.K.B., Wongsuwan, H., Homhual, S., (2011) Experimental study of wood downdraft gasification for an improved 


\section{International Journal of Science and Research (IJSR) \\ ISSN (Online): 2319-7064}

Index Copernicus Value (2013): 6.14 | Impact Factor (2015): 6.391

producer gas quality through an innovative two-stage air and premixed air/gas supply approach Bioresource Technology,doi:10.1016/j.biortech.2010.12.024

[4] Kathirvale, S., Yunus, M.M., Sopian, K., Samduddin, A.H., (2004).Energy potentialfrommunicipal solid waste in Malaysia. Renewable Energy 29 (4), pp 559-567.

[5] Narvaez, I., Orı, A., Aznar, M. P., Corella, J., (2004) Biomass Gasification with Air in an Atmospheric Bubbling Fluidized Bed. Effect of Six Operational Variables on the Quality of the Produced Raw Gas, Ind. Eng. Chem. Res. Vol. 35, pp. 2110-2120.

[6] Singh, R.P., Tyagi, V.V., Allen, T., Hakimi Ibrahim, M., Hakimi Ibrahim, M., Kothari, R., (2011). An overview for exploring the possibilities of energy generation frommunicipal solid waste (MSW) in Indian scenario. Renew. Sust. Energy Rev. 15(9), 4797-4808.

[7] Themelis, J.N and Alexander, K.,(2003),Energy recovery from municipal solid waste by gasification. ASME international Tampa FL, pp 241-252.

[8] Robinson, K., Thomas, M, and Catherine, N. (2005). District strategic plan 2005 - 2010, implementation of the national population policy for sustainable development, published by National Coordination Agency for Population and Development.

[9] ASTM D2504-88(1998) Standard Tests methods for non condensable gases in $\mathrm{C}_{2}$ and Lighter Hydrocarbon products by Gas Chromatography, Annual Book of ASTM standards, Vol 5.01,ASTM, 100 Bar harbor Drive, west Conshohocken, PA19428 USA. 